\title{
Characterization of shelters of the giant otter (Pteronura brasiliensis, Mammalia, Carnivora, Mustelidae) in the pantanal wetlands, state of Mato Grosso, Brazil
}

\author{
Júnio de Souza Damasceno ${ }^{1,2,5}$; Marília Couto Silva Shiraiwa ${ }^{2,6}$ \& Júlio César Dalponte ${ }^{3,4,7}$ \\ 1 Pontifícia Universidade Católica de Minas Gerais (PUC-MINAS), Programa de Pós Graduação em Biologia de Vertebrados. \\ Belo Horizonte, MG, Brasil. \\ ${ }^{2}$ Universidade Federal de Mato Grosso (UFMT), Instituto de Biociências (IB), Centro de Biodiversidade, \\ Programa de Pós-Graduação em Ecologia e Conservação da Biodiversidade (PPG-ECB). Cuiabá, MT, Brasil. \\ ${ }^{3}$ Universidade Federal de Mato Grosso (UFMT), Instituto de Ciências Naturais, Humanas e Sociais (ICNHS). Sinop, MT, Brasil. \\ ${ }^{4}$ Instituto para a Conservação dos Carnívoros Neotropicais (Pró-Carnívoros). Atibaia, SP, Brasil. \\ ${ }^{5}$ ORCID: http://orcid.org/0000-0001-9282-221X.E-mail: jdamascenobh@gmail.com \\ ${ }^{6}$ ORCID: http://orcid.org/0000-0001-9588-757X. E-mail: marilias@gmail.com \\ 7 ORCID: http://orcid.org/0000-0002-7086-5144. E-mail: jcdalponte@hotmail.com
}

\begin{abstract}
The giant otter (Pteronura brasiliensis) is an endangered mammal that occupies aquatic environments, especially in the Amazon Rainforest and Pantanal wetlands in South America. The species uses shelters (dens and campsites), such as burrowed tunnels and tangles of branches and roots along watercourses, where it feeds mainly on fishes. In Espírito Santo Creek (northern portion of the Pantanal wetlands in the state of Mato Grosso, Brazil), 60 shelters (45 dens and 15 campsites) were identified and georeferenced during 12 fieldtrips between 2002 and 2003. The density was $1.8 \mathrm{dens} / \mathrm{km}$. The shelters were significantly found in locations with partial (35\%) or complete (55\%) plant cover. The dens were dug mainly in soil associated with roots located, on average, $4.4 \mathrm{~m}$ in distance and $2.4 \mathrm{~m}$ in height in relation to the waterline. The campsites had a significantly smaller distance and height compared to the dens. The greater density of dens in the study area underscores the need for conserved environments with little human interference for the protection of giant otter populations. The vegetal coverage of riparian forests and the occurrence of ravines along Espírito Santo Creek offer greater protection to the shelters, hindering the access of predators to the interior of the shelter. Studies integrating biological and ecological knowledge with social participation in areas of occurrence of the giant otter are fundamental to the conservation of the species and its habitat in the Pantanal wetlands of Mato Grosso, Brazil.
\end{abstract}

Keywords. Giant Otter; Pteronura brasiliensis; Dens; Campsites; Pantanal.

\section{INTRODUCTION}

The giant otter, Pteronura brasiliensis (Zimmermann, 1780), is the largest species of otter in the world. It is endemic to tropical forests and floodplains in South America, living in rivers, creeks, and lakes (Schenck et al., 1999; Carter \& Rosas, 1997; Duplaix et al., 2015).

The species forms groups of two to 16 individuals that are organized hierarchically, with a breeding pair and juveniles from different litters (Duplaix, 1980; Schweizer, 1992; Carter \& Rosas, 1997; Leuchtenberger et al., 2013; Duplaix et al., 2015). The groups may include members that are not related reproductively, but all members cooperate in the defense of their territory (Duplaix et al., 2015) as well as during activities of foraging, patrolling, reproduction, and the protection of pups (Duplaix, 1980; Laidler, 1984; Schweizer, 1992; Carter \& Rosas, 1997).

Giant otters construct shelters on the banks of rivers, bays, creeks, dams, and lakes within their living areas (Duplaix, 1980; Schweizer, 1992; Carter \& Rosas, 1997; Lima et al., 2012). These shelters are used regularly for rest in a large part of the areas but may be used temporarily to raise pups (Laidler, 1984). The physical structure of the dens consists of an ascending tunnel opening into a wide underground chamber that the otters use for shelter (Duplaix, 1980; Schweizer, 1992).

Giant otters also maintain shelters denominated campsites within their territory. Campsites are 
semicircular or rectangular areas on the banks of rivers or lakes where the otters clear the vegetation and regularly use for the marking of scents to signal their territory and as observation points (Duplaix, 1980; Laidler, 1984; Schweizer, 1992; Carter \& Rosas, 1997). These campsites have a sandy substrate and are naturally devoid of vegetation, differing from the communal latrines, which consist of a small clearing formed by trampled vegetation (Duplaix, 1980; Schweizer, 1992; Lima et al., 2012).

Habitat selection for the construction of shelters seems to be influenced by environmental variables related to plant coverage, structure, accessibility, and the slope of the bank (Duplaix, 1980). Other aspects involve the spatiotemporal dynamics of the environment, such as complex hydrological interactions and characteristics that influence processes of flooding and erosion (Lima et al., 2012; Duplaix et al., 2015). However, the species faces several threats to its habitat (Rosas et al., 2015; Groenendijk et al., 2015), such as pollution and the difficulty in establishing conservation units for the protection of giant otter populations in the Pantanal wetlands (Groenendijk \& Hajek, 2002; Tomas et al., 2015; Leuchtenberger et al., 2020).

The giant otter was transferred from the category of "vulnerable" to "endangered" by the International Union for Conservation of Nature (IUCN) in 2000 (Duplaix et al., 2008), where it has remained to the present day (Groenendijk et al., 2015). In Brazil, Pteronura brasiliensis is classified as "vulnerable" by the Instituto Chico Mendes de Biodiversidade (ICMBio, 2018).

Areas of distribution of the giant otter in the Amazon Rainforest and Pantanal wetlands are impacted by the destruction and accelerated fragmentation of its natural habitats as well as the construction of dams, which alters the dynamics of aquatic communities and the food wed of fish-eating species, such as the giant otter (Rodrigues et al., 2013). In the Pantanal wetlands, studies on the characterization and monitoring of giant otter shelters were first conducted by Schweizer (1992). In the Amazon, a detailed study by Lima et al. (2012) as well as important contributions from Carter \& Rosas (1997), Rosas et al. (2007), and Palmeirim et al. (2014) helped build knowledge on the habitats and shelters of the species in Brazilian ecosystems, based on discoveries by Duplaix (1980) in Suriname and Laidler (1984) in the Guianas. However, the constant threat to natural ecosystems in the Pantanal wetlands stemming from the expansion of human activities requires efforts directed at the ecological knowledge of biodiversity as well as the identification and characterization of priority areas for conservation and the monitoring of giant otter populations and habitats in the Pantanal wetlands.

The Pantanal has been affected by the progressive loss of natural habitats for deforestament and burning. More that 20,000 fire alerts were registed in 2020; three times the historical average (1998-2020) (INPE, 2020). From 1988 to 2019, the Mato Grosso state had already deforested $146,140 \mathrm{~km}^{2}$ of natural habitats (Shimabukuro et al., 2020), lost natural cover area equivalent to Pantanal along the last 30 years. The fire emissions associated with deforestation in native vegetation of the Amazon and Pantanal may doubt on Brazil's ability to meet its greenhouse gas emissions reduction goal by 2030 (Silva-Júnior et al., 2020). Therefore, destruction and degradation of natural ecosystems are posing serious risks to human health, wildlife and agricultural biodiversity in short, medium and long-term effects of distinct impacts levels (FIOCRUZ, 2020).

The aim of the present study was to characterize shelters of the giant otter in Espírito Santo Creek, which is located in the Natural Heritage Private Reserve pertaining to SESC Pantanal in the municipality of Barão de Melgaço, state of Mato Grosso, Brazil.

\section{MATERIAL AND METHODS}

\section{Study Area}

The Pantanal wetlands constitute the largest floodplains on the planet $\left(140,000 \mathrm{~km}^{2}\right)$ and are formed by tributaries of the Paraguay River. The altitude of the plain ranges from 60 to $150 \mathrm{~m}$ (average: $100 \mathrm{~m}$ ). The climate is tropical, semi-humid, with a mean annual temperature of $25^{\circ} \mathrm{C}$ (Signor et al., 2010).

Biotic and abiotic processes in the Pantanal are determined by flood patterns, which are fundamental to ecological interactions among biological communities. Seasonal hydrological fluctuations enable the cycling of nutrients, contribute to the diversity of organisms, and establish the dynamics of movements and migrations driven by the availability of resources and habitats (Signor et al., 2010).

The SESC Natural Heritage Private Reserve is located in the municipality of Barão de Melgaço and is bordered by the Cuiabá and São Lourenço Rivers. The reserve has a total area of 106,588 ha located in the northern portion of the Pantanal wetlands in the state of Mato Grosso (16 to $17^{\circ} \mathrm{S}$ and 56 to $57^{\circ} \mathrm{W}$ ) (Antas et al., 2011).

The temperature in the reserve fluctuates between $22^{\circ}$ and $32^{\circ} \mathrm{C}$ and is associated with plant coverage, with lower temperatures in dense forest and humidity higher than $70 \%$. Average annual precipitation is between 1,100 to 1,200 $\mathrm{mm}$ (Hasenack et al., 2010).

The densely forested physiognomy that occurs in seasonally flooded areas of the reserve is dominated by Vochysia divergens Pohl (Vochysiaceae) (Hofmann et al., 2010). Rivers and creeks are lined with gallery forests and semi-deciduous forest in higher areas, with inundated banks in the rainy season. The fauna and flora are related to the Cerrado (savanna) biome of central Brazil (Alho et al., 2008). The mean level of the Cuiabá River in the reserve between 1999 and 2012 reached a maximum of $4.15 \pm 0.40 \mathrm{~m}$ in March and a minimum of $1.31 \pm 0.39 \mathrm{~m}$ in September (Antas et al., 2016).

Espírito Santo Creek is a long channel that was once part of the main bed of the Cuiabá River. Its length is determined by the dry and flood seasons in the Pantanal. The creek is located from $16^{\circ} 30^{\prime} \mathrm{S}$ and $56^{\circ} 14^{\prime} \mathrm{W}$ to $16^{\circ} 35^{\prime} \mathrm{S}$ and $56^{\circ} 22^{\prime} \mathrm{W}$ (Antas et al., 2016) and has marginal chan- 

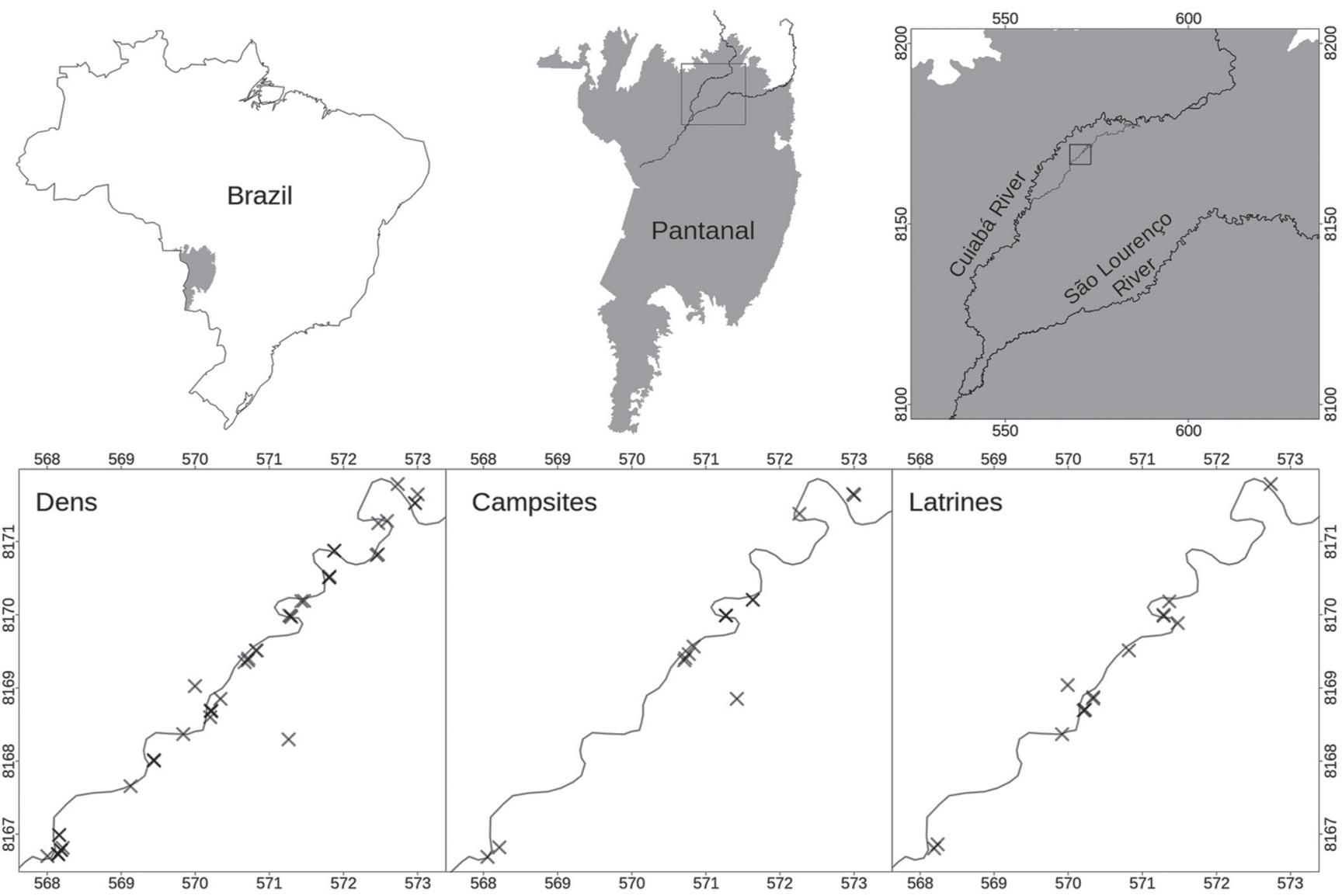

Figure 1. Demarcation of shelters (dens and campsites) and latrines of giant otter in Espírito Santo Creek, Natural Heritage Private Reserve, SESC Pantanal, municipality of Barão de Melgaço, northern portion of Pantanal, state of Mato Grosso, Brazil.

nels interconnected with other water bodies, especially in flat flooded areas between Espírito Santo Creek and the Cuiabá River (Fig. 1).

Espírito Santo Creek has a depth of five meters in the flood season and its directional flow with the Cuiabá River is interrupted in the dry season, accentuated by silting from human-built secondary channels (Antas et al., 2016), maintaining indirect communication through secondary channels and narrower water bodies with bays and small lakes. The width of the creek between banks ranges from 100 to $200 \mathrm{~m}$ throughout its length in the dry season and the margins are predominantly covered by dense gallery forest. Some stretches of the creek are not formed by ravines and have sandy beaches with flat margins covered by grasses up to the waterline.

\section{Data collection}

The banks of Espírito Santo Creek were inspected for the localization and identification of types of shelters during 15 fieldtrips between 2002 and 2003. Twenty km were travelled along the creek. Each shelter was georeferenced with geographic coordinates in UTM. Records made regarding activity (active or inactive shelter), type of use, and structure (classified as dens and campsites). A shelter was considered active based on recent vestiges (new latrine, scent marking, ground wet by pawprints, or the presence of individuals).
Dens are characterized as tunnels burrowed into the bank of the creek used for nocturnal shelter, resting, and the raising of pups. Campsites are refuges on the margins of the aquatic environment associated with latrines to signal territory used as stopover grounds and sometimes bearing claw marks on the banks (Groenendijk et al., 2005).

The giant otters recent sightings of active dens and individuals have yet been found in Corixo Espírito Santo (Neves, C.C., pers. comm.) that share relevance to conservation of $P$. brasiliensis in Pantanal.

\section{Data analysis}

The shelters were analyzed based on three levels of plant coverage (uncovered, partially covered, or completely covered). In this study, plant coverage refers to vegetation of a riparian forest, including the canopy of the trees, trunks, and roots in the surroundings of a shelter, offering camouflage and protection or hindering the access of predators. The uncovered level was defined as the absence of riparian forest vegetation over the shelter. The partially covered level regarded the occurrence of riparian vegetation with part of the shelter visually uncovered. The completely covered level was characterized by a shelter under riparian forest vegetation that was not visible from the riverbed. The chi-squared test with Yates' correction was used to evaluate the frequency of shelters 
located in uncovered, partially covered, and completely covered areas.

Distance and height in relation to the waterline and the slope of the bank were measured at each shelter. Slope was measured by the angle of inclination of the ground in relation to the flat surface of the creek at the entrance of the shelter. Two measurements were made to determine the angle of the slope $(\alpha)$ : height $(\mathrm{H})$ of the base of the shelter (den, campsite, or resting site) to the waterline and distance (D) from the base of the shelter to the waterline. The measurements were made using two 2-m rulers and two squares and were calculated in a trigonometric equation [hypothenuse $(a)=H / D ; a^{\circ}=\operatorname{arc}$ tangent of hypothenuse].

Active and inactive shelters were compared using the Hotteling test to determine significant differences regarding the variables measured. Dens and campsites were compared using the $t$-test for the analysis of distance and height in relation to the waterline. All statistical tests were performed with the aid of BioEstat 5.0 (Ayres et al., 2007).

\section{RESULTS}

Sixty shelters were identified along Espírito Santo Creek (45 dens and 15 campsites), with densities of 2.3 dens $/ \mathrm{km}$ and 0.8 campsites $/ \mathrm{km}$. Regarding vegetation, six shelters (10\%) were in uncovered areas, 21 (35\%) were in partially covered areas, and 33 (55\%) were in completely covered areas (Table 1). In terms of substrate, 36 shelters were associated with root systems and 24 were associated with sandy soil and clay. Thirty shelters were active and 30 were inactive.

The distribution map revealed that the dens were distributed along the entire length of the study area. Campsites and latrines were distributed at more specific points and corresponded to similar locations in the study area (Fig. 1).

The shelters located in completely covered $\left(X^{2}=17.333 ; p<0.0001\right)$ and partially covered $\left(X^{2}=7.259\right.$; $p<0.001)$ areas were significantly more frequent than those in areas covered by riparian forest. No significant

Table 1. Characterization of shelters of giant otter (Pteronura brasiliensis) in Espírito Santo Creek, Natural Heritage Private Reserve, SESC Pantanal. Data refer to mean length and height of entrance to den, width of campsite, slope of bank, distance from shelter to waterline and height of shelter in relation to waterline.

\begin{tabular}{lcc}
\hline \multicolumn{1}{c}{ Characterization of shelters } & Dens $^{\mathbf{1}}(\mathbf{n}=\mathbf{4 5})$ & Campsites $^{\mathbf{2}}(\mathbf{n}=\mathbf{1 5})$ \\
\hline Length $(\mathrm{cm})$ & 91.0 & 186.5 \\
Entrance height ${ }^{1} /$ Width $^{2}(\mathrm{~cm})$ & 41.1 & 56.7 \\
Slope of bank $\left({ }^{\circ}\right)$ & 30.1 & 29.4 \\
Distance to waterline $(\mathrm{cm})$ & 440 & 280 \\
Height in relation to waterline $(\mathrm{cm})$ & 240 & 170 \\
\hline \multicolumn{1}{c}{ Vegetation cover } & Dens $^{\mathbf{1}}(\mathbf{n}=\mathbf{4 5})$ & Campsites $^{\mathbf{2}}(\mathbf{n}=\mathbf{1 5})$ \\
\hline Uncovered & 3 & 3 \\
Partially Covered & 15 & 6 \\
Completely Covered & 27 & 6 \\
\hline
\end{tabular}

difference in frequency was found between completely and partially covered areas.

The shelters were, on average, four meters in distance from the waterline (range: 0.9 to $7.8 \mathrm{~m}$ ) and 2.3 meters in height in relation to the waterline (range: 0.5 to $3.6 \mathrm{~m}$ ). Active and inactive shelters had similar characteristics regarding these variables. The Hotteling test revealed no significant differences $(T 2=4.1698 ; F=0.7764 ; p=0.429)$ (Table 1).

The dens had an average length of $91.0 \mathrm{~cm}$ (range: 40 to $200 \mathrm{~cm}$ ) and average height of $41.1 \mathrm{~cm}$ (range: 18 to $85 \mathrm{~cm}$ ) and were built on banks with an average slope of $30.1^{\circ}$ (range: $17^{\circ}$ to $52^{\circ}$ ). The campsites had an average length of $186.5 \mathrm{~cm}$ (range: 110 to $550 \mathrm{~cm}$ ) and average width of $56.7 \mathrm{~cm}$ (range: 37 to $100 \mathrm{~cm}$ ) and were located on banks with an average slope of $29.4^{\circ}$ (range: $14^{\circ}$ to $45^{\circ}$ ) (Table 1).

The dens were located, on average, $4.4 \mathrm{~m}$ (range: 1.0 to $7.8 \mathrm{~m}$ ) in distance from the waterline and den height was, on average, $2.4 \mathrm{~m}$ (range: 0.7 to $3.6 \mathrm{~m}$ ) in relation to the waterline. The campsites were located, on average, $2.8 \mathrm{~m}$ (range: 0.9 to $5.3 \mathrm{~m}$ ) in distance from the waterline and $1.7 \mathrm{~m}$ (range: 0.5 to $3.2 \mathrm{~m}$ ) in height in relation to the waterline (Table 1). Statistically significant differences between dens and campsites were found regarding distance $(t=3.4292 ; p=0.0011)$ and height $(t=3.5428$; $p=0.0008)$ in relation to the waterline. The campsites were generally closer to the water than the dens.

\section{DISCUSSION}

\section{Characterization of shelters}

The density of giant otter shelters in Espírito Santo Creek (2.3 dens $/ \mathrm{km}$ ) is greater than that reported in studies conducted in the Amazon, which registered 0.47 dens $/ \mathrm{km}$ (Palmeirim et al., 2014) and $1.01 \mathrm{dens} / \mathrm{km}$ (Lima et al., 2012). The density is even higher when considering both dens and campsites, reaching 3.0 shelters/ $\mathrm{km}$. The large number of dens may be related to the density of individuals or the size of the groups. A comparative study on the giant otter in areas of the Pantanal wetlands between 2001 and 2011 revealed that the Espírito Santo Creek had a higher mean group size $(6.0 \pm 1.0)$ and number of individuals per kilometer (0.74) than means found in other areas of the Pantanal (4.8 \pm 0.57 and $0.54 \pm 0.15$, respectively) (Tomas et al., 2015). However, the relation between the number of dens and density of individuals is not clearly identified in the study area.

The lower frequency of campsites in comparison to dens may be related to the greater availability of stable banks for building dens. In areas with unstable ravines or without ravines, campsites are used as resting grounds (Lima et al., 2012; Duplaix, 1980) but the otters are potentially vulnerable to attack from sympatric predators, such as the jaguar (Panthera onca) (Linnaeus, 1758) (e.g., Ramalheira et al., 2015), which requires strategies to minimize the risk. In the Pantanal wetlands, campsites are rare in the dry season, but a higher incidence occurs in 
flood periods, when the banks are inundated, and in the presence of family groups that use these shelters as territorial marks (Schweizer, 1992).

The similarity in the distribution of campsites and latrines has been reported by specialists (Groenendijk et al., 2005; Lima et al., 2012) and confirms the use of these points for resting, observation, and marking territory. Moreover, the more specific distribution of campsites and latrines, as found in the present study, suggests the defense of specific areas with better feeding prospects (Carter \& Rosas, 1997) as well as the defense of habitats and dens that are strategically more important to the survival of the groups of otters, which exhibit greater habitat selectivity in the dry season (Leuchtenberger et al., 2013).

The significant presence of plant cover in shelter areas and the large number of dens in Espírito Santo Creek indicate the importance of riparian forests along watercourse as a habitat requirement for the giant otter. Carter \& Rosas (1997) found that $96 \%$ of dens studies in the Amazon were located in areas with at least 50\% arboreal coverage. Likewise, Lima et al. (2012) recorded $67 \%$ vegetation at the entrance of dens. The giant otter prefers making dens in places camouflaged by branches and leaves than exposed in areas without vegetation (Schweizer, 1992). The presence of giant otters is favored by the greater availability of shelters in habitats with easy access to watercourse in safe areas covered with vegetation and with sufficient feeding resources (Lima et al., 2012).

The slope of the bank in areas with dens and campsites $\left(30^{\circ}\right)$ was similar to data described by Lima et al. (2012) in Amanã Lake $\left(29^{\circ}\right)$. In contrast, Palmeirim et al. (2014) described a mean slope of $\left(17^{\circ}\right)$ at Balbina Dam in the Amazon, although dens were found on banks with a slope ranging from $46^{\circ}$ and $60^{\circ}$ in the headwater rivers of the reservoir.

The combination of riparian forest vegetation with tangles of roots, branches, and spines and the slope of the banks are important characteristics of shelters that offer greater stability against erosion and hinder the access of potential predators. The need for protection was evident in the present study on three separate occasions in which caimans (Caiman crocodilus yacare) (Daudin, 1802) gained access to the interior of abandoned dens on banks with a low slope and little plant coverage. Although groups of otters can catch and feed on caimans ( $C$. crocodilus) in the Pantanal wetlands, such events are likely associated with the scarcity of food sources (Ribas et al., 2012). In contrast, solitary otters and pups are potentially vulnerable to attacks from other mammals and predatory reptiles (Duplaix, 1980; Laidler, 1984; Ramalheira et al., 2015).

The mean height of the entrance of the dens in Espírito Santo Creek $(41 \mathrm{~cm})$ is similar to that reported in studies conducted in the Amazon (Rosas et al., 2007; Lima et al., 2012). However, the width of the dens along Espírito Santo Creek is up to twofold (Lima et al., 2012) and fourfold (Rosas et al., 2007) greater than that of dens in the Amazon. Smaller entrances may indicate more re- cently constructed dens (Duplaix, 1980; Schweizer, 1992), which would explain the differences found between the Amazon and Pantanal (Lima et al., 2012). Other hypotheses need to be evaluated, such as the participation of more members of the group building simultaneously, the contribution of the specific plant cover composing each den both to increasing protection against invasion and preventing erosion, as well as the influence of the size of the individuals and groups in different habitats to enable a more effective defense of the den entrance.

The constructions of dens associated mainly with root systems has been reported in previous studies (Duplaix, 1980; Schweizer, 1992; Carter \& Rosas, 1997). However, Lima et al. (2012) recorded dens mainly dug directly in the ground and associated with the roots and stems of the riparian vegetation.

The significant difference between dens and campsites regarding distance and height in relation to the waterline is likely related to the purpose of these type of shelters in Espírito Santo Creek. As they were related to the distribution of the latrines, one hypothesis would be that campsites in this environment are used specifically as observation points and temporary resting grounds during movements to feeding areas and for the defense of these feeding areas. The proximity to the water would minimize energy during flight from terrestrial predators, as the giant otter has more limited locomotion capacity on land than in the water.

The larger distance of the shelters in the Pantanal wetland compared to that reported in study conducted in the Amazon (Lima et al., 2012) may indicate the greater effect of the flood pulse in wetland environments and the occurrence of resident groups using dens in Espírito Santo Creek. Although no studies have evaluated the entire flood season, local park guards report the presence of otters in the same place even in the flood season in the Pantanal. Moreover, the mean difference in the water level of the Cuiabá River in the area of the SESC Natural Heritage Private Reserve between the flood and dry seasons is approximately three meters (Antas et al., 2016) and at least $27 \%$ of the dens recorded in the present study were above this height in relation to the water level. This would explain the large number of dens distributed throughout the entire study area, suggesting alternance in the use of dens in the same area during the hydrological fluctuation in the dry and flood seasons.

\section{Habitat Conservation}

The SESC Natural Heritage Private Reserve in the Pantanal wetlands has well conserved areas with little human interference. The practice of fishing is occasional in the reserve and there were no signs of predatory fishing or degradation of the environment. More specific studies on the minimum requirements for the maintenance of giant otter populations in aquatic environments are fundamental to establishing conservation units and the degree of restrictive measures necessary to ensure the protection of areas for the shelter, feeding, 
and reproduction of the giant otter throughout its area of distribution.

Espírito Santo Creek is also in a good state of conservation with little human interference. However, this important wildlife refuge as well as adjacent areas are seriously threatened by activities linked to the expanding fishing tourism along the Cuiabá River and Pantanal wetlands (Santos \& Jesuz, 2014). Moreover, the contamination of the environments and aquatic biotic due to mineral exploration and the presence of mercury related to gold mining (Vieira \& Alho, 2004), the exposure of sediments to pesticide residues (Possavatz et al., 2014), and construction of dams, which impede the reestablishment of migratory populations and can even permanently eliminate such populations (Smith et al., 2020), are worrisome impacts in the northern portion of the Pantanal and the basin of the Cuiabá River.

The loss of riparian forests along watercourses and the consequent increase in human activities and interference in natural environments are serious threats to the conservation of wild habitats. The protection of species may depend on the greater availability of refuges (Weinberger et al., 2019) as well as more specific, selective ecological requirements, which are fundamental to the survival of endangered species.

The habitats of the giant otter are seriously threatened by the trend of global climate change, which alters seasonal rainfall patterns, with striking effects on the dynamics of flood pulses in the Pantanal wetlands. Tozato et al. (2013) identified a tendency toward a reduction in the volume of rains and an increase in the temperature in the Pantanal in a 40-year period (1971 and 2011), stating that this scenario favors the expansion of areas for livestock activities, which already exert considerable pressure on this biome.

Although the population is currently in expansion (Tomas et al., 2015), the protection of $P$. brasiliensis is a challenge in the Pantanal, as population estimates are analyzed in ecologically stable environments that are balanced in terms of the availability of resources. The dependence on the maintenance of flood pulse patterns for the sustainability of giant otter populations in the Pantanal (Rodrigues et al., 2013) place the species under threat in Brazil (ICMBio, 2018), requiring conservation programs for the ecological balance of its habitats (Groenendijk et al., 2004; Duplaix et al., 2015). To face these challenges, the effects of the main factors that threaten biodiversity in the Pantanal need to be addressed: (1) the conversion of natural vegetation for livestock and agricultural activities; (2) the alteration of natural habitats; (3) the burning of natural vegetation; (4) the change in rainfall and flood patterns; (5) unregulated tourism; and (6) the introduction of exotic species (Alho et al., 2019).

The present study underscores the need for the protection of natural areas so that the giant otter can build shelters in preserved riparian forest environments with adequate feeding resources and little human interference in the Pantanal. The conservation of giant otter populations depends on efforts to ensure the maintenance of habitats with capacity to support the ecological balance throughout the upcoming decades, which will require political and economic actions aligned with recommendations generated through scientific knowledge.

In 2010, the Instituto Chico Mendes de Conservação da Biodiversidade (ICMBio [Chico Mendes Biodiversity Conservation Institute]) established the National Action Plan for the Conservation of Otters in two study cycles (2010-2015 and 2016-2020) developed by specialists in research involving Pteronura brasiliensis and Lontra longicaudis (ICMBio, 2016). The results of these studies will enable important advances toward the conservation of these species and the protection of their habitats in the main biomes of Brazil and will offer a basis for knowledge building to enable the reversal of the scenario of setbacks and serious environmental crises in the current policy of environmental protection and monitoring in the country.

Studies with the aim of raising social awareness and building knowledge on the biological and ecological aspects of the giant otter are fundamental to minimizing conflicts between otter populations and local residents as well as tourism and fishing activities. Moreover, civil society, the scientific community, and biodiversity protection agencies need to conduct organized joint actions due to the difficult mission of reconciling proposals for the conservation of biodiversity with political/economic interests as well as the environmental changes that will continue to place pressure on the biota of these natural environments in upcoming decades.

\section{ACKNOWLEDGMENTS}

The authors are grateful to the Coordenação do Projeto Pantanal Norte [Coordination of the Northern Pantanal Project], Programa de Estudos Ecológicos de Longa Duração (PELD [Long-Duration Ecological Studies Program]), PPG/ECB-UFMT, CAPES for the post-graduate grant, the National Council for Scientific and Technological Development (CNPq) for funding the present study and the Natural Heritage Private Reserve of SESC Pantanal (RPPN SESC Pantanal) for logistics support and fieldwork related research. and the interns and technicians of the Vertebrate Collection of Universidade Federal de Mato Grosso. The authors offer special thanks to the technicians Evanildo Albuquerque and Francisco de Assis Rondon for their assistance in the field and to Dr. João Batista de Pinho (PPG-ECB/UFMT) and Cristina Cuiabália Neves (SESC Pantanal) for news informations about giant otters.

\section{AUTHORS' CONTRIBUTIONS}

Junio Damasceno: Experimental design, conduct of experiments. Formal analysis and interpretation of data and writing of the manuscript (original). Writing: review and editing. Julio Dalponte: Interpretation of data and interpretation of results. Writing: review and editing. Marília Shiraiwa: Coordinator and Supervision of re- 
search project and experimental design. Writing: review and editing. All the authors actively participated in the discussion of the results, they reviewed and approved the final version of the paper.

\section{CONFLICT OF INTEREST}

The authors declare that there is no conflict of interest regarding the publication of this article.

\section{REFERENCES}

Alho, C.J.R. 2008. Biodiversity of the Pantanal: response to seasonal flooding regime and to environmental degradation. Brazilian Journal of Biology, 68(4, Suppl.):957-966. D0I

Alho, C.J.R.; Mamede, S.B.; Benites, M.; Andrade, B.S. \& Sepúlveda, J.J.0. 2019. Ameaças à Biodiversidade do Pantanal Brasileiro pelo uso e ocupação da terra. Ambiente \& Sociedade, 22: e01891. D0I

Antas, P.T.Z.; Carrara, L.A.; Ubaid, F.K.; Oliveira-Júnior, S.B.; Ferreira, L.P. 2016. Aves coloniais das praias da Reserva Particular Natural SESC Pantanal.. Rio de Janeiro, SESC, Departamento Nacional, 2016. 236p. (Conhecendo o Pantanal 10). https://www.sescpantanal.com.br/arquivos/cadastroitens/layout-6/arquivos/file-636004641681109890.pdf.

Antas, P.T.Z.; Oliveira, L.F.B.; Pádua, M.T.J.; Pereira, N.C. \& Vanutky, W.W. 2011. Plano de Manejo da Reserva Particular do Patrimônio Natural do SESC Pantanal Leopoldo Garcia Brandão (Coordenação). 2. ed. Rio de Janeiro, SESC, Departamento Nacional, 2011. 148p. (Conhecendo o Pantanal 3) https://ava.icmbio.gov.br/portal/images/stories/docs-planos-demanejo/rppn sesc pantanal.pdf.

Ayres, M.; Ayres-Jr., M.; Ayres, D.L. \& Santos, A.A.S. 2007. BioEstat 5.0: Aplicações estatísticas nas áreas das ciências bio-médicas. Belém/PA, Sociedade Civil Mamirauá. 364p.

Carter, S.K. \& Rosas, F.C.W. 1997. Biology and conservation of the giant otter, Pteronura brasiliensis. Mammal Review, 27(1): 1-26. D01

Duplaix, N. 1980. Observations on the ecology and behaviour of the giant river otter Pteronura brasiliensis in Suriname. Terre et La Vie, 34(4): 495-620.

Duplaix, N.; Evangelista, E. \& Rosas, F.C.W. 2015. Advances in the study of giant otter (Pteronura brasiliensis) ecology, behavior, and conservation a review. Latin American Journal of Aquatic Mammals, 10(2): 75-98. D0I

Duplaix, N.; Waldemarin, H.F.; Groenekijk, J.; Evangelista, E.; Munis, M.; Valesco, V. \& Botello, J.C. 2008. Pteronura brasiliensis. In: IUCN 2011. IUCN Red List of Threatened Species. Version 2011.2. Available: https://www. iucnredlist.org. Access: 25/05/2012.

Fundação Oswaldo Cruz (FIOCRUZ). 2020. Incêndios Florestais no Pantanal 2020. Fundação Oswaldo Cruz (Ministério da Saúde) Nota Técnica 01: 1-11. Available: https://agencia.fiocruz.br/sites/agencia.fiocruz.br/files/ u34/nt 01 pantanal final1.pdf. Access: 16/02/2021.

Groenendijk, J. \& Hajek F. 2002. Giant otter project in Peru. Field trip and activity report - 2001. IUCN Otter Specialist Group Bulletin, 19(1): 30-39.

Groenendijk, J.; Duplaix, N.; Marmontel, M.; Van Damme, P. \& Schenck, C. 2015. Pteronura brasiliensis. The IUCN Red List of Threatened Species 2015 : e.T18711A21938411. Available: DOI. Access: 18/05/2019.

Groenendijk, J.; Hajek, F. \& Schenck, C. 2004. Pteronura brasiliensis. The IUCN Red List of Threatened Species 2004: e.T18711A8507915. Access: 20/07/2020.

Groenendijk, J.; Hajek, F.; Duplaix, N.; Reuther, C.; Van Damme, P.; Schenck, C. \& Botello, J.C. 2005. Surveying and monitoring distribution and population trends of the giant otter (Pteronura brasiliensis) - Guidelines for a standardization of survey methods as recommended by the giant otter section of the IUCN/SSC Otter Specialist Group. Habitat, 16: 1-100.

Hasenack, H.; Cordeiro, J.L. \& Hofmann, G.S. 2010. Macroclima, o clima regional, e mesoclima, o clima local. In: SESC. 0 clima na Reserva Particular de Patrimônio Natural SESC Pantanal. Rio de Janeiro, SESC, Departamento Nacional, 2010. p. 62-82. Available: https://www.sescpantanal.com.br/ arquivos/cadastro-itens/layout-6/arquivos/file-635877033338581527.pdf.

Hofmann, G.S.; Hasenack, H.; Oliveira, L.F.B. 2010. Microclima e a estrutura de formações vegetais. In: SESC. O clima na Reserva Particular de Patrimônio Natural SESC Pantanal. Rio de Janeiro, SESC, Departamento Nacional, 2010. p. 11-53. Available: https://www.sescpantanal.com.br/arquivos/ cadastro-itens/layout-6/arquivos/file-635877033338581527.pdf.

Instituto Chico Mendes de Conservação da Biodiversidade (ICMBio). 2016. Plano de Ação Nacional para Conservação da Ariranha (Pteronura brasiliensis). PAN Ariranha. Instituto Chico Mendes de Conservação da Biodiversidade. Brasília (DF), ICMBio. (Série Espécies Ameaçadas № 28. $2^{\circ}$ Ciclo 2016-2020). Available: https://www.icmbio.gov.br/portal/ faunabrasileira/plano-de-acao-nacional-lista/149-pan-ariranha. Access: 20/07/2020.

Instituto Chico Mendes de Conservação da Biodiversidade (ICMBio). 2018. Livro Vermelho da Fauna Brasileira Ameaçada de Extinção. Brasília, DF, Instituto Chico Mendes de Conservação da Biodiversidade. v. 1, 492p.

Instituto Nacional de Pesquisas Espaciais (INPE). 2020. Monitoramento dos focos ativos por bioma (Queimadas). Programa Queimadas - Instituto Nacional de Pesquisas Espaciais. Available: http://queimadas.dgi.inpe. br/queimadas/portal-static/estatisticas estados. Access: 16/02/2021.

Laidler, P.E. 1984. The behavioural ecology of the giant otter in Guyana. PhD. Thesis, University of Cambridge. 296p.

Leuchtenberger, C.; Oliveira-Santos, G.R.; Magnusson, W. \& Mourão, G. 2013. Space use by giant otter groups in the Brazilian Pantanal. Journal of Mammalogy, 94(2): 320-330. D01

Leuchtenberger, C.; Rheigantz, M.L.; Zucco, C.A.; Catella, A.C.; Magnusson W.E. \& Mourão, G. 2020. Giant otter diet differs between habitats and from fisheries offtake in a large Neotropical floodplain. Journal of Mammalogy, 101(6): 1650-1659. DOI

Lima, D.S.; Marmontel, M. \& Bernard, E. 2012. Site and refuge use by giant river otters (Pteronura brasiliensis) in the Western Brazilian Amazonia. Journal of Natural History, 46(11-12): 729-739. D0I

Palmeirim, A.F.; Peres, C.A. \& Rosas, F.C.W. 2014. Giant otter population responses to habitat expansion and degradation induced by a mega hydroelectric dam. Biological Conservation, 174: 30-38. D0I

Possavatz, J.; Zeilhofer, P.; Pinto, A.A.; Tives, A.L. \& Dores, E.F.G.C. 2014. Resíduos de pesticidas em sedimento de fundo de rio na Bacia Hidrográfica do Rio Cuiabá, Mato Grosso, Brasil. Revista Ambiente e Água, 9(1): 83-96. DOI

Ramalheira, C.S.; Bozzetti, B.F.; Cruz, A.D.; Palmeirim, A.F.; Cabral, M.M.M. \& Rosas, F.C.W. 2015. First record of jaguar predation on giant otter (Pteronura brasiliensis). Animal Biology, 65: 81-86. D01

Ribas, C.; Damasceno, G.; Magnusson, W.; Leuchtenberger, C. \& Mourão, G. 2012. Giant otters feeding on caiman: evidence for an expanded trophic niche of recovering populations. Studies Neotroprical Fauna Environmental, 47(1): 19-23. D0I

Rodrigues, L.A.; Leuchtenberger, C. \& Silva, V.C.F. 2013. Avaliação do risco de extinção da Ariranha. Pteronura brasiliensis (Zimmermann, 1780) no Brasil. Biodiversidade Brasileira, 3(1): 228-239.

Rosas, F.C.W.; de Mattos, G.E. \& Cabral, M.M.M. 2007. The use of hydroelectric lakes by giant otters (Pteronura brasiliensis): The case of Balbina dam in Central Amazonia, Brazil. Oryx, 41(4): 520-524. DOI

Rosas, F.C.W.; Ramalheira, C.S.; Bozzetti, B.F.; Palmeirim, A.F. Cruz, A.D.; Pathek, D.B. \& Cabral; M.M.M. 2015. Sleeping Sites Used by Giant Otters 
(Pteronura brasiliensis) in the Balbina Hydroelectric Reservoir, Central Brazilian Amazon. Aquatic Mammals, 41(2): 143-148. D0I

Santos, I.R.S. \& Jesuz, C.R. 2014. A Técnica do Discurso do Sujeito Coletivo na Percepção da Qualidade da Água do Rio Cuiabá - MT. Revista Mato-Grossense de Geografia, 17(1): 117-138. Available: https:// periodicoscientificos.ufmt.br/ojs/index.php/geografia/article/view/733.

Schenck, C.; Groenendijk, J. \& Hajek, F. 1999. Giant Otter Project in Peru. Field trip and activity report-1998. IUCN Otter Specialist Group Bulletin, 16(1):33-42.

Schweizer, J. 1992. Ariranhas no Pantanal. Ecologia e Comportamento da Pteronura brasiliensis. Curitiba, Editora Brasil Natureza (EDIBRAN). 200p.

Shimabukuro, Y.E.; Dutra, A.C.; Arai, E.; Duarte, V.; Cassol, H.L.G.; Pereira, G. \& Cardozo, F.S. 2020. Mapping Burned Areas of Mato Grosso State Brazilian Amazon Using Multisensor Datasets. Remote Sensing, 12: 3827. D01

Signor, C.A.; Fernandes, I.M. \& Penha, J. 2010. 0 Pantanal e 0 sistema de pesquisa. In: Fernandes, I.M.; Signor, C.A.; Penha, J. (Orgs.). Biodiversidade no Pantanal de Poconé. Cuiabá, MT, Centro de Pesquisa do Pantanal. 196p. Available: https://ppbio.inpa.gov.br/sites/default/files/ Livro Pocone Ebook.pdf.

Silva-Júnior, C.A.; Teodoro, P.E.; Delgado, R.C.; Teodoro, L.P.R.; Lima, M.; Pantaleão, A.A.; Baio, F.H.R.; Azevedo, G.B.; Azevedo, G.T.O.S.; Capristo-
Silva, G.F.; Arvor, D. \& Facco, C.U. 2020. Persistent fire foci in all biomes undermine the Paris Agreement in Brazil. Scientific Report, 10: 16246. DOI

Smith, C.; Whitworth, A.; Brunner, E. \& Pomilia, M. 2020. Habitat selection and diet of the Neotropical otter (Lontra longicaudis) on the Osa Peninsula, Costa Rica, and range-wide monitoring recommendations. Neotropical Biodiversity, 6: 1: 62-74. D0I

Tomas, W.M.; Camilo, A.R.; Ribas, C.; Leuchtenberger, C.; Borges, P.A.L.; Mourão, G. \& Pellegrin, L.A. 2015. Distribution and conservation status of giant otter (Pteronura brasiliensis) in the Pantanal wetland, Brazil. Latin American Journal of Aquatic Mammals, 10(2): 107-114. D0I

Tozato, H.C.; Dubreuil, V. \& De Mello-Théry, N.A. 2013. Tendências e Rupturas Climato-Hidrológicas no Sítio Ramsar PARNA Pantanal (MT, Brasil). Revista Brasileira de Climatologia, 9(13): 164-184. DOI

Vieira, L.M. \& Alho, C.J.R. 2004. Contaminação por mercúrio em sedimento e moluscos da Bacia do Rio Bento Gomes, MT. - Boletim de Pesquisa e Desenvolvimento, Corumbá, 58:1-20. Available: https://ainfo.cnptia. embrapa.br/digital/bitstream/item/37304/1/BP58.pdf.

Weinberger, I.C.; Muff, S.; Kranz, A. \& Bontadina, F. 2019. Riparian vegetation provides crucial shelter for resting otters in a human-dominated landscape. Mammalian Biology, 98: 179-187. D01 